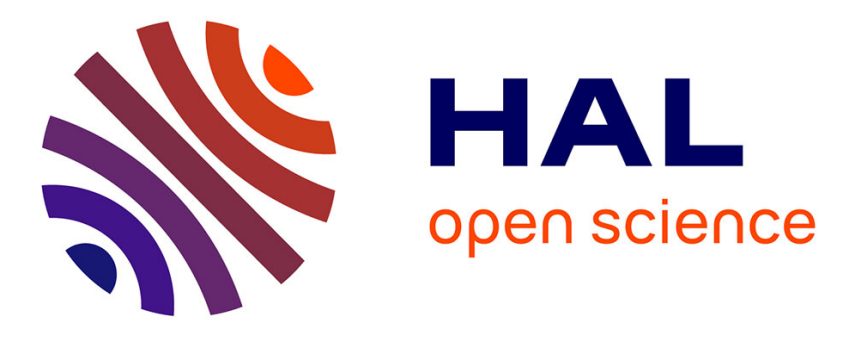

\title{
Mediterranean woody plant specialized metabolites affect germination of Linum perenne at its dry and upper thermal limits
}

Hazem Hashoum, Arne Saatkamp, Thierry Gauquelin, Julien Ruffault, Catherine Fernandez, Anne Bousquet-Mélou

\section{To cite this version:}

Hazem Hashoum, Arne Saatkamp, Thierry Gauquelin, Julien Ruffault, Catherine Fernandez, et al.. Mediterranean woody plant specialized metabolites affect germination of Linum perenne at its dry and upper thermal limits. Plant and Soil, 2020, 446, pp.291-305. 10.1007/s11104-019-04366-6 . hal02425147

\section{HAL Id: hal-02425147 \\ https://hal-amu.archives-ouvertes.fr/hal-02425147}

Submitted on 9 Jan 2020

HAL is a multi-disciplinary open access archive for the deposit and dissemination of scientific research documents, whether they are published or not. The documents may come from teaching and research institutions in France or abroad, or from public or private research centers.
L'archive ouverte pluridisciplinaire HAL, est destinée au dépôt et à la diffusion de documents scientifiques de niveau recherche, publiés ou non, émanant des établissements d'enseignement et de recherche français ou étrangers, des laboratoires publics ou privés. 
1 Mediterranean woody plant specialized metabolites affect germination of Linum perenne at its dry and upper thermal limits

4 Hazem Hashoum ${ }^{*}$, Arne Saatkamp ${ }^{1^{*}}$, Thierry Gauquelin, Julien Ruffault, Catherine Fernandez,

5 Anne Bousquet-Mélou

6 Aix Marseille Université, IMBE UMR 7263, CNRS, IRD, Université d'Avignon

7 1 corresponding author, e-mail: arne.saatkamp@imbe.fr, * authors contributed equally

\section{Abstract}

9 Aims: Soil temperature and moisture impact plants not only during growth and survival but also 10 during seed germination and interaction of seeds with the chemical environment. The quantitative 11 impacts of either temperature and moisture or plant specialized metabolites (PSM) on germination 12 are widely studied. However, the combined effect of PSM and moisture or temperature on 13 germination remains poorly understood.

14 Methods: We addressed this issue by studying the effect of PSM extracted from four Mediterranean 15 woody plants on germination speed and final percentages of a subordinate herbaceous plant, Linum 16 perenne.

17 Results: By using hydro- and thermal time threshold models, we show how PSM interact with 18 temperature and moisture levels to limit germination at dry and upper thermal limits, with the 19 magnitude of effects depending on the source plant. PSM effects on germination, also observed on 20 natural soils, persisted after their removal from the seed environment.

21 Conclusions: We conclude that the impact of climate change on reproduction of herbaceous plants

22 can be modulated by effects of PSM from woody plants, which might exacerbate the negative 23 impacts of global changes on biodiversity.

24 Keywords: Plant Specialized Metabolites, allelopathy, allelochemicals, climate change 


\section{Introduction}

26 Climate change induces unpreceded warming and drought in many parts of the world (Giorgi and

27 Lionello 2008; Hoerling et al. 2012) and modify ecosystems not only by altering adult plant growth

28 and survival but also by modifying plant regeneration and plant-plant interactions (Klanderud 2005).

29 Plant-plant interactions are sensitive to climatic changes and include many more chemical

30 interactions involving plant specialized metabolites (PSM) than previously thought (Fernandez et al.,

31 2015, Rasman and Agrawal, 2011). Germination is particularly sensitive to PSM (Fernandez et al.

32 2013) and also shows a fine-tuned sensibility to soil water potentials and temperatures that decide on

33 its success (Bradford et al., 2008). Whereas the effects of PSM on germination have been largely

34 studied for a large range of source and target species (Fernandez et al. 2006; Flematti et al. 2004;

35 Herranz et al. 2006; Jefferson and Pennacchio 2003; Ruprecht et al. 2008; Souto et al. 2001), we lack

36 knowledge on how chemical cues affect the seed environment and seed sensibility under different

37 warming and drought conditions.

38 A comprehensive way to study the effects of warming and drought on the seed environment consists

39 of using population-based threshold models (Bradford 2002; Huang et al. 2016), since they can 40 capture the effect of chemicals in the seed environment (Bradford et al. 2008; Liptay and Schopfer 41 1983; Ni and Bradford 1992). Population-based models capture the limiting effects of exceeding

42 cold, warm or dry conditions by using base temperature $\left(\mathrm{T}_{\mathrm{b}}\right)$ as minimal temperature threshold, 43 ceiling temperature $\left(\mathrm{T}_{\mathrm{c}}\right)$ as maximum temperature threshold and base water potential $\left(\Psi_{\mathrm{b}}\right)$ as 44 minimum moisture threshold parameter (Bradford 2002). Together with a time and dispersion 45 parameter, germination speed and final percentages can be modeled for any temperature or water 46 potential (Bradford 2002). Since threshold parameters encapsulate the response to the entire range of 47 temperature and water conditions for germination, they are emerging functional traits for 48 regeneration processes (Arène et al. 2017; Saatkamp et al. 2019) and give a deep insight on how 
49 germination is affected by both, climatic conditions of the environment and the chemical

50 environment (Bradford et al. 2008). Until now, there has been no attempt to use germination

51 threshold models to study the effects of PSM and to reveal how climatic changes might interact with

$52 \quad$ PSM during plant regeneration.

53 PSM importantly explain how plants interact with their biotic and abiotic environment (Rasmann and

54 Agrawal 2011; Williams et al. 1989). However, the difficulties to study the seed environment below

55 ground and at the soil surface during germination (Saatkamp et al. 2011; Saatkamp et al. 2019) limit

56 our understanding on the role of chemical cues in nature until now. Release of PSM exert toxic or

57 stimulatory effects on other plants (Rice 1984) and in this way changes the outcome of competition

58 and the reproduction of competing plants by increasing the fitness of source plants (Rasmann and

59 Agrawal 2011; Williams et al. 1989). However, recent works also show that chemical interactions

60 vary between ecosystems and according to subtle changes in soil moisture and temperature (Blanco

61 2007). Temperature and water stresses may increase the production of PSM in the environment

62 (Allemann et al. 2016; Briggs et al. 2009; Einhellig 1996; Lobón et al. 2002; Ma et al. 2015;

63 Melkania 1992; Wang et al. 2011) and increase the toxicity of PSM (Allemann et al. 2016; Einhellig

64 and Eckrich 1984; Gatti et al. 2014; Oueslati et al. 2005; Wang et al. 2011). Interestingly, also a

65 plant's sensitivity to PSM can be modified by environmental factors (Einhellig 1996; Lobón et al.

66 2002; Wang et al. 2011). At the level of seed physiology, PSM can act as plant growth inhibitors

67 (Fernandez et al. 2015; Hashoum et al. 2017; Scognamiglio et al. 2013), in an analog way to abscisic

68 acid (ABA). ABA is a well-known signal substance in plants that inhibits germination and has

69 opposite roles compared to gibberellic acid (GA3) in regulating germination (Holdsworth et al. 2008;

70 Vesty et al. 2016). Moreover, ABA has been shown to play a role in limiting germination at high

71 temperatures (Benech-Arnold et al. 2006) by decreasing germination speed and final percentages 
72 (Bradford et al 2008). Studying PSM together with exposure to GA3 may hence increase our

73 understanding of the mechanisms behind the interactions of PSM with climatic extremes.

74 In Mediterranean forests, PSM released into the environment play a prominent role at the ecosystem

75 level, by inhibiting germination and growth of neighboring plants, and modifying soil communities

76 (Fernandez et al. 2015; Hashoum et al. 2017). Emission of volatile organic compounds and leaching

77 rate of PSM are particularly high and respond strongly to climatic changes in the Mediterranean

78 (Chomel et al. 2016; Fernandez et al. 2015; Gavinet et al. 2018). While PSM attain target plants by

79 volatile emissions, root exudates, leaching from green leaves or during decomposition of senescent

80 leaves (Herranz et al. 2006; Rice 1984; Ruprecht et al. 2008), some authors stress that the main PSM

81 involved in chemical plant-plant interactions are water-soluble (Vyvyan 2002). Mediterranean

82 woody plants, such as Quercus pubescens Willd. (Fagaceae), Pinus halepensis Mill. (Pinaceae), Acer

83 monspessunalum L. (Aceraceae) and Cotinus coggygria Scop. (Anacardiaceae) are known for the

84 inhibitory effect of their PSM on both, germination and growth (Fernandez et al 2013; Fernandez et

85 al. 2016; Hashoum et al 2017). Climate in the Mediterranean is characterized by rapid transitions

86 between dry summers and moist winters and a high inter-annual variability in rainfall. Climate

87 models also agree on increasing drought conditions for the next decades in this area (Hoerling et al.

88 2012). Mediterranean forest ecosystems are hence a prominent model to study how PSM interact

89 with temperature and drought and at which level PSM inhibit seed germination, interacting with

90 hormone levels inside seeds or with substrate characteristics.

91 The main objective of this study is hence to unravel the mechanisms that link the climatic niche of

92 seed germination to different types of PSM in Mediterranean ecosystems. More specifically, we

93 address whether (1) PSM from the leaves of Mediterranean woody plants interact with temperature

94 and water in their effect on germination speed and percentages of a subordinate herbaceous plant,

95 Linum perenne L., (2) natural soils reduce the effect of aqueous PSM leaf extracts on germination, 
96 (3) the duration and timing of seed exposure to PSM impact their effects on germination niche and,

97 (4) PSM may counteract the effects of GA3 and inhibit germination in a similar way to ABA.

\section{Material and Methods}

100 Seed material

101 We used seed material from Linum perenne variety 'Lin vivace bleu' purchased from Vilmorin SA 102 (La Ménitré, Limagrain, France). L. perenne is distributed in temperate and Mediterranean Europe 103 and overlaps substantially with the distribution areas of $Q$. pubescens, A. monspessulanum, $C$. 104 coggygria and P. halepensis. Moreover, this species occurs naturally in forest margins and semi105 open habitats associated with these woody plants.

Plant specialized metabolites

108 Green leaves from the three dominant woody plants naturally present in Downy oak forests were 109 collected at the Oak Observatory at the Observatoire de Haute Provence (OHP) located $60 \mathrm{~km}$ north 110 of Marseille, South of France ( $43^{\circ} 56^{\prime} 115^{\prime \prime}$ N, $05^{\circ} 42^{\prime} 642^{\prime \prime}$ E). The site is $680 \mathrm{~m}$ above sea level and 111 presents a mean annual temperature of $11.9^{\circ} \mathrm{C}$ and a mean annual precipitation of $830 \mathrm{~mm}(1967$ 112 2000). This forest was managed for centuries by coppicing, dominated by Downy oak (Q. pubescens;

$11375 \%$ coverage) and Montpellier maple (A. monspessulanum; 25\% coverage), with understory

114 vegetation dominated by smoke tree (C. coggygria; 30\% coverage); Aleppo pine (P. halepensis)

115 occurs in initial successional stages on drier and warmer habitats around the study site and might 116 increase due to climate change.

117 In order to study changes in PSM during senescence we also sampled senescent leaves from $C$. 118 coggygria. A previous study identified senescent leaves in C. coggygria to have a markedly different 119 chemical composition and a significantly stronger allelopathic effect compared to the other species 
120 (Gavinet et al. 2019; Hashoum et al. 2017). Leaves and needles were harvested in summer 2013 at

121 the OHP and then kept in the freezer at $-20^{\circ} \mathrm{C}$ until the beginning of the experiment.

122 Since PSM are mainly released into the environment through rain and dew leachates transferring leaf 123 compounds to the soil (Herranz et al. 2006; Rice 1984; Ruprecht et al. 2008), we chose to mimic 124 natural leachates in this study through foliar aqueous extracts from fresh and senescent leaves.

125 Leaves of the four sources species ( $Q$. pubescens, A. monspessulanum, $C$. coggygria and $P$. 126 halepensis) were soaked in deionized water to obtain $1 \%$ aqueous extracts, we standardized by dry 127 weight of leaves after drying parts of the sample for $72 \mathrm{~h}$ in an oven at $60^{\circ} \mathrm{C}$. Extracts were left at 128 room temperature in darkness for 24 hours. This protocol enables to extract a maximum of PSM by 129 limiting their degradation (Souto et al. 1994). They were then filtered through a filter paper 130 (Whatman No 1). Extracts were stored at $4{ }^{\circ} \mathrm{C}$ until the start of the experiments.

131 We measured the osmolality (mOsmol/ $\mathrm{kg} \mathrm{H}_{2} \mathrm{O}$ ) of all extracts using a micro-osmometer from 132 Roebling (Type13/13DR - Autocal) to ensure that the inhibitory effects observed on germination 133 rate and growth were not due to osmotic pressures but to PSM (Anderson and Loucks 1966). The 134 osmometer was recalibrated every 10 samples with deionized water and certified solution of 300 $135 \mathrm{mOsmol} / \mathrm{kg} \mathrm{H} \mathrm{H}_{2} \mathrm{O}$.

137 Preparation of Polyethylene glycol (PEG) solutions

138 Water potentials used in our experiments were simulated by the use of PEG8000 according to the 139 equations provided by Michel (Michel 1983) taking into account the temperatures of incubation 140 chambers and setting the PEG concentrations in order to obtain water potentials of -0.5 , and -0.2 $141 \mathrm{MPa}$ and $0 \mathrm{MPa}$ (pure water). PEG solutions were then added into Petri dishes containing two 142 Whatman No 2. 
145 Bioessays

146 Five different germination experiments (summarized in Table 1) were carried out to meet the 147 objectives of our study. All germination experiments were done with Petri dishes, which were 148 regularly controlled and watered. Petri dishes were sealed when water potentials were controlled by 149 PEG solutions. Growth chambers were used to perform germination experiments under controlled 150 conditions of constant temperature and $12 \mathrm{~h}$ of light (cool white fluorescent tubes, \pm 10000 lux; \pm $\left.151250 \mu \mathrm{mol} \mathrm{m}{ }^{-2} \cdot \mathrm{s}^{-1}\right)$. Germinations were controlled daily during the first week, then once per week until 152 the end of the experiment. Seeds with extruding white radicles were counted and removed on every 153 control. Germination experiments lasted 3-4 weeks according to speed of germination in the different 154 conditions and were stopped when $90 \%$ of germination was reached. We did not remove seeds that 155 just split their seed coats open, as in L. perenne there can be 1-2 days delay between seed coat 156 splitting and appearance of the radicle. For all experiments and for each treatment, four replicates of 15725 seeds were used, extracts were applied once at the first watering and, as a control, seeds were 158 watered with deionised water. All seeds sown without PEG solutions were regularly watered with 159 deionised water. Petri dishes with PEG-solutions were filmed. The experiments lasted between 21 160 and 42 days in order to reach the maximum possible germination for each tested condition.

\section{Interaction of PSM, temperature and water potential}

162 In order to test the interaction of PSM with temperature and water potential conditions on 163 germination, we varied PSM concentration, temperature and water potentials experimentally in 164 germination tests (Experiment 1 and 2 in Table 1). First, we studied the effects aqueous extracts of 165 green leaves from all source species (A. monspessulanum, P. halepensis, Q. pubescens, and C. 166 coggygria) on germination using temperatures of $10,15,20$ and $25{ }^{\circ} \mathrm{C}$. We also included 167 germination trials at $5,18,22$ and $30^{\circ} \mathrm{C}$ using extracts of $A$. monspessulanum to complement our 
168 data. The range of temperatures covered temperatures during the germination season in the habitat of 169 source and target species. Second, we studied the interactions of reduced water potentials using PEG 170 concentrations equivalent to -0.2 and $-0.5 \mathrm{MPa}$ at temperatures of $10,15,20$, and $25{ }^{\circ} \mathrm{C}$, in order to

171 know if PSM, temperature and reduced water potential interact on limiting seed germination. We 172 also aimed to quantify the differences between green and senescent leaves by adding senescent 173 leaves of C. coggygria using temperatures of $5,10,15,18,20,22,25$ and $30{ }^{\circ} \mathrm{C}$ with reduced water 174 potential equivalent to -0.2 and $-0.5 \mathrm{MPa}$ at $15,20,22,25$ and $30^{\circ} \mathrm{C}$.

\section{Interaction of exposition time and substrate with PSM effects}

177 One of our objectives was to test whether a temporary exposition to PSM still had a limiting effect 178 on germination. To this end, we temporarily exposed 25 seeds in four replicate Petri dishes per 179 treatment to green leaf extracts of A. monspessulanum. A. monspessulanum was one of the source 180 species with the strongest inhibiting effect on germination (Experiment 3 in Table 1). In this setting, 181 seeds were exposed to water in the beginning, then from day 4 to day 10 to leaf extracts of $A$. 182 monspessulanum and then again to water. For a second treatment, we first exposed seeds to leaf 183 extracts of $A$. monspessulanum and then from day 4 to day 10 to water and then again to leaf 184 extracts. We also used two control treatments: one where seeds where only watered with deionised 185 water and another with seeds being permanently exposed to leaf extracts of $A$. monspessulanum. All 186 treatments were kept at $25^{\circ} \mathrm{C}$ constant temperature.

187 Moreover, we also wanted to know if PSM interact with natural soil. Therefore, we compared 188 germination of $L$. perenne on filter paper with germination on natural soil from the study site as 189 substrate (Experiment 4 in Table 1). Natural soil from the study site is a clay rich, mollic leptosol 190 (IUSS Working Group 2006), with pH 7.5 and low active lime content. We performed this 191 experiment at $25^{\circ} \mathrm{C}$. In this experiment, we used 25 seeds in four replicate Petri dishes per treatment. 
Interaction of gibberellic acid (GA3) and PSM on germination at high temperature

194 In order to test the interaction of PSM and gibberellic acid on germination, we performed bioassays 195 using seeds that had been in contact with GA3 at $50 \mathrm{ppm}$ during $24 \mathrm{~h}$ and, as a control, seeds without 196 GA3 treatment (Experiment 5 in Table 1). After that, seeds were divided and sown either with leaf 197 extracts of $A$. monspessulanum or with water as a control during 3 weeks at $25^{\circ} \mathrm{C}$.

Table 1: Description of the five germination experiments and their respective objectives carried out in this study. PSM of four source species were extracted: Quercus pubescens, Pinus halepensis, Acer monspessulanum and Cotinus cogyggria. Green leaves were used for the four species and scenescent leaves were also studied for Cotinus cogyggria. For experiment 1, we additionally included data from 5, 18, 22 and $30^{\circ} \mathrm{C}$ for the treatment with extracts from Acer monspessulanum leaves; all

experiments were performed with 25 seeds in each of four replicate Petri dishes per treatment.

\begin{tabular}{|c|c|c|}
\hline No & Objectives & Methods \\
\hline 1 & $\begin{array}{l}\text { Quantify interaction between plant specialized } \\
\text { metabolites (PSM) and temperature for } \\
\text { germination }\end{array}$ & $\begin{array}{l}\text { Germination trials at } 10,15,20 \text { and } 25^{\circ} \mathrm{C} \\
\text { with PSM of four woody plants* and a } \\
\text { control treatment }\end{array}$ \\
\hline 2 & $\begin{array}{l}\text { Quantify interaction between PSM and } \\
\text { moisture }\end{array}$ & $\begin{array}{l}\text { Germination trials at } 10,15,20,22 \text { and } \\
25^{\circ} \mathrm{C} \text { PEG concentrations equivalent to } 0,- \\
0.2 \text { and }-0.5 \mathrm{MPa}\end{array}$ \\
\hline 3 & $\begin{array}{l}\text { Test reversibility and resilience of PSM effects } \\
\text { during germination }\end{array}$ & $\begin{array}{l}\text { Germination trial at } 25^{\circ} \mathrm{C} \text { exposition to Acer } \\
\text { monspessulanum extracts continuously for } \\
21 \text { days, from day } 4 \text { to day } 10 \text {, until day } 4 \\
\text { and after day } 10 \text { and no exposition control }\end{array}$ \\
\hline 4 & Test if soil vs filter paper modify PSM effects & $\begin{array}{l}\text { Germination trials at } 25^{\circ} \mathrm{C} \text { on filter paper } \\
\text { and on natural soil, with and without } \\
\text { extracts from Acer monspessulanum }\end{array}$ \\
\hline 5 & Test interaction between GA3 and PSM & $\begin{array}{l}\text { Germination trials at } 25^{\circ} \mathrm{C} \text { with and without } \\
\text { Acer monspessulanum extracts combined } \\
\text { with and without exposition to } 50 \text { ppm GA3 } \\
\text { during } 24 \mathrm{~h}\end{array}$ \\
\hline
\end{tabular}


208 We used thermal time and hydrotime modelling to study the effects of different leachates on the

209 germination behavior of $L$. perenne seed populations and more specifically how the relationship 210 between seed environment - seed germination is influenced by PSM. Thermal time and hydrotime 211 models of germination use the parameters of temperature and water potential threshold values, as 212 well as parameters for speed and dispersion in order to predict the germination timing over the entire 213 range of temperature and water potentials used in the experiments. These models also synthesize 214 information from many different germination trials into few ecological meaningful parameters. This 215 enabled us to compare effects of PSM on germination in a comprehensive way. Since our data 216 showed non-linear trends of base water potentials to temperature (Fig. 4A), we decided not to use 217 hydro-thermal time models that require a linear relation. Hence, we used three separate germination 218 models: (i) suboptimal thermal time models, (ii) hydrotime models, (iii) and supraoptimal thermal 219 time models. For these three models, we compared parameters fitted for germination data from pure 220 water and from each PSM treatment.

222 (i) Suboptimal thermal time models were used for all germination data from $5^{\circ}$ to $18^{\circ} \mathrm{C}$. We decided 223 to use $18{ }^{\circ} \mathrm{C}$ as cut-off value since previous analysis of temperature effects on germination speed 224 (measured as the inverse of time needed for $50 \%$ of seeds to germinate) showed a linear increase 225 until $18^{\circ} \mathrm{C}$. The cumulative germination proportions $(\mathrm{G})$ were modelled as a function of temperature 226 and time to germination $\left(\mathrm{t}_{\mathrm{g}}\right)$ according to equation 1 , we linearized germination proportions using 227 probit-transformation.

$$
\operatorname{probit}(\mathrm{G})=\frac{\log 10\left(\left(\mathrm{~T}_{\text {env }}-\mathrm{T}_{\mathrm{b}}\right) \mathrm{t}_{\mathrm{g}}\right)-\log 10\left(\theta_{\mathrm{TT}}\right)}{\sigma_{\theta_{\mathrm{TT}}}}
$$


231 This model has three free parameters: base temperature $\mathrm{T}_{\mathrm{b}}\left[{ }^{\circ} \mathrm{C}\right]$, thermal time constant $\theta_{\mathrm{TT}}\left[{ }^{\circ} \mathrm{C} \mathrm{x}\right.$

232 days] and a dispersion parameter $\sigma_{\mathrm{eTT}}$ capturing the dispersion around $\theta_{\mathrm{TT}}$ measured on the scale of 233 thermal time. We estimated $\mathrm{T}_{\mathrm{b}}\left[{ }^{\circ} \mathrm{C}\right]$, thermal time constant $\theta_{\mathrm{TT}}\left[{ }^{\circ} \mathrm{C} \mathrm{x}\right.$ days $]$ and $\sigma_{\theta \mathrm{TT}}$ using maximum234 likelihood by minimizing sum log-likelihood of differences between observed and estimated probit235 transformed germination proportions $(\operatorname{probit}(\mathrm{G}))$. We used the log-transformed thermal time to 236 linearize the relationship between germination proportions and thermal time. We also retrieved 95\% 237 confidence intervals using the quadratic method implemented in confint and mle functions in the 238 bbmle package in R (Bolker 2017).

239 (ii) Supra-optimal thermal time models were fitted to germination data using the regression of 240 probit-transform of germination proportions against supra-optimal thermal time.

$$
\operatorname{probit}(G)=\frac{T_{c(g)}-\theta_{T T} / t_{g}+T_{e n v}}{\sigma_{T_{c}}}
$$

244 We estimated thermal time $\theta_{\mathrm{TT}}$, ceiling temperature $\mathrm{T}_{\mathrm{c}}$ and its dispersion parameter $\sigma_{\mathrm{Tc}}$ using 245 maximum-likelihood by minimizing sum log-likelihood of differences between observed and 246 estimated probit-transformed germination proportions (probit $(\mathrm{G})$ ), note that the dispersion parameter 247 takes negative values because the slope of the relation between germination proportions and 248 temperatures above the optimum is negative. We used all experimental data from temperatures above $24920{ }^{\circ} \mathrm{C}$ to model supra-optimal of germination of L. perenne seeds. 
250 (iii) Hydrotime models were fitted for germination data at water potentials of $0,-0.2$ and $-0.5 \mathrm{MPa}$ 251 simulated by different concentrations of PEG (see above) at temperatures of 15,20 and $25^{\circ}$. We

252 discarded data from an experiment with PEG at $10^{\circ} \mathrm{C}$ because of too few germinations.

253 In this case, the probit transform of cumulative germination was modelled as a function of 254 environmental water potential $\left(\Psi_{\text {env }}\right)$, time to germination $\left(t_{\mathrm{g}}\right)$ using the following equation:

$$
\operatorname{probit}(G)=\frac{\Psi_{\mathrm{b}(\mathrm{g})}-\theta_{\mathrm{H}} / \mathrm{t}_{\mathrm{g}}-\Psi_{\mathrm{env}}}{\sigma_{\Psi_{\mathrm{b}}}}
$$

258 We estimated the parameters using maximum-likelihood by minimizing sum log-likelihood of 259 differences between observed and estimated probit-transformed germination proportions (probit(G)), 260 the estimated parameters were three: base water potential $\Psi_{\mathrm{b}}$ its dispersion parameter $\sigma_{\psi b}$ and 261 hydrotime constant $\theta_{\mathrm{H}}[\mathrm{MPa} \mathrm{x}$ days].

262 We compared PSM effects on final germination percentages within specific temperature and water 263 potential treatments (Fig. 1C, 2C and 3C) using one-way analysis of variance followed by Tukey's 264 honest significant difference test, results of which we plotted as letters into figures.

265 Finally, we tested the interactions of PSM and GA3 using a two-way ANOVA on germination 266 percentages. 
Results

\section{Germination and thermal time models at sub-optimal temperatures}

270 PSM significantly reduced germination speed in terms of thermal time needed for germination

271 compared to the control experiment (Fig. 1A and B). Thus, the 95\% confidence intervals of the

272 thermal time constant $\theta_{\mathrm{T} 50}$ for $L$. perenne germination under influence of PSM of $A$.

273 monspessulanum and senescent $C$. cogyggria leaves did not overlap with the $\theta_{\mathrm{T} 50}$ of the control

274 treatment without PSM (Tab. 2). Contrastingly, the 95\% confidence intervals of base temperature for

275 germination $\mathrm{T}_{\mathrm{b}}$ and dispersion $\sigma_{\mathrm{e} T 50}$ (slope in Fig. 1A) overlapped between control and all metabolite

276 treatments, suggesting that germination speed and not temperature requirements are affected by PSM

277 at sub-optimal temperatures. However, at suboptimal temperatures, PSM did not impact final

278 germination percentages (Fig. 1C), albeit a slight increase could be detected for P. halepensis

279 compared to extracts from senescent leaves of Cotinus cogyggria.
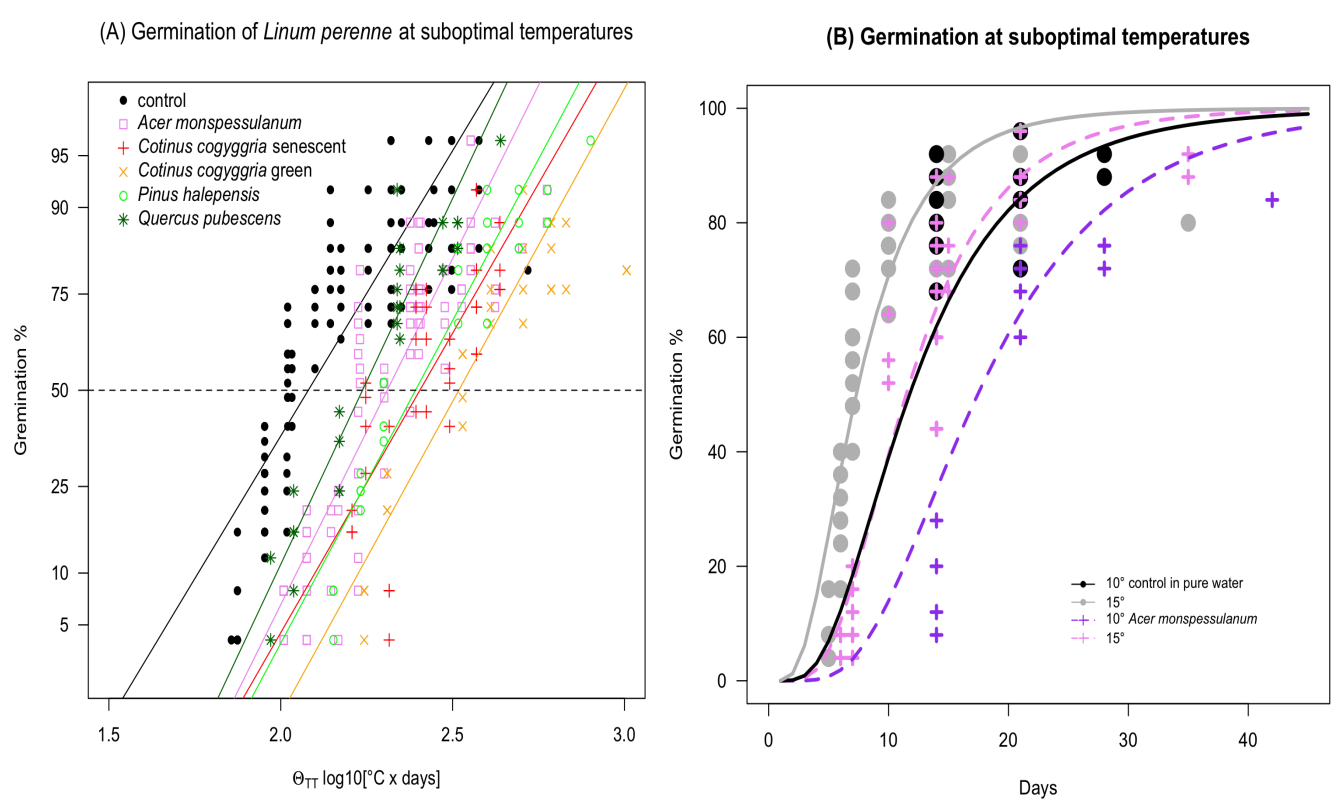

(C) Germination $\%$ at $15^{\circ} \mathrm{C}$

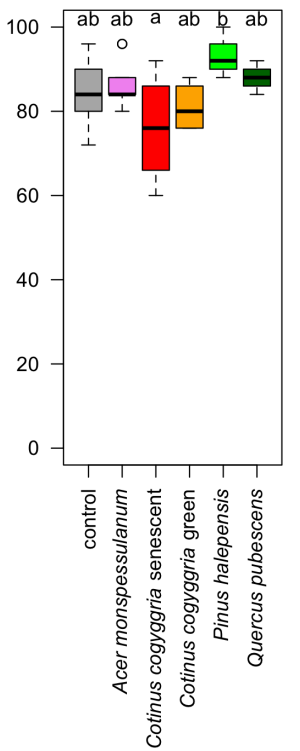

281 Fig. 1 (A) Effect of plant specialized metabolites (PSM) on germination speed of L. perenne in suboptimal temperatures in water; germination observations are standardized to log-thermal time, $\theta_{\mathrm{T}(\mathrm{g})}$, using base temperature $\mathrm{T}_{\mathrm{b}}$ according to Table 1, germination proportions are on probit-scale; coloured lines according to thermal time parameters in Table 1; (B) Example of observed germination dynamics and thermal time model for germination of $L$. perenne seeds in water and in $A$. monspessulanum green leaf extracts at 10 and $15^{\circ} \mathrm{C}$; (C) Final germination percentages of L. perenne 
at $15^{\circ} \mathrm{C}$ for control and five PSM treatments, letters indicate significant differences $(p<0.05)$ in a

Table 2 Maximum-likelihood estimation of thermal time model parameters for germination in the

suboptimal temperature range $\left(<20^{\circ} \mathrm{C}\right)$ for seeds of L. perenne. Plant specialized metabolites (PSM)

treatments: Germination in pure water $(\mathrm{N})$, with $1 \%$ aqueous extract of green leaves of $A$.

293 monspessulanum (A), C. cogyggria (Cg), Q. pubescens (Q), P. halepensis (P) and 1\% aqueous

294 extract of senescent leaves of C. cogyggria (Cs); values in brackets are $95 \%$ confidence intervals.

\begin{tabular}{|c|c|c|c|c|c|}
\hline PSM & $\begin{array}{l}\text { Base temperature } T_{b} \\
{\left[{ }^{\circ} \mathrm{C}\right]}\end{array}$ & $\begin{array}{l}\text { Thermal time constant } \\
\theta_{\mathrm{T} 50} \\
{\left[{ }^{\circ} \mathrm{C} \times \mathrm{d}\right]}\end{array}$ & $\begin{array}{l}\text { Dispersion } \\
\text { parameter } \sigma_{\theta \mathrm{T} 50} \\
\log 10\left[{ }^{\circ} \mathrm{C} \times \mathrm{d}\right]\end{array}$ & $\mathbf{R}^{2}$ & $\mathbf{N}$ \\
\hline control & $0.04(-1.90-1.97)$ & $120.26(102.62-137.90)$ & $0.25(0.22-0.28)$ & 0.72 & 135 \\
\hline A & $-2.00(-4.76-0.76)$ & $204.05(165.93-242.17)$ & $0.21(0.18-0.23)$ & 0.79 & 79 \\
\hline Cs & $-2.68(-7.45-2.10)$ & $253.95(172.55-335.36)$ & $0.24(0.16-0.32)$ & 0.57 & 36 \\
\hline $\mathrm{Cg}$ & $-14.15(-31.54-3.24)$ & $329.64(118.91-540.37)$ & $0.23(0.19-0.26)$ & 0.88 & 24 \\
\hline $\mathrm{P}$ & $-13.46(-33.49-6.56)$ & $246.58(63.21-429.95)$ & $0.22(0.19-0.25)$ & 0.88 & 26 \\
\hline $\mathrm{Q}$ & $-0.58(-4.79-3.62)$ & $172.94(116.84-229.03)$ & $0.19(0.16-0.23)$ & 0.88 & 21 \\
\hline
\end{tabular}

\section{Supra-optimal thermal time and ceiling temperature}

298 Table 3 Thermal time model parameters for germination in the supra-optimal temperature range $299\left(>20^{\circ} \mathrm{C}\right)$ for seeds of L. perenne; Plant specialized metabolites (PSM) : Germination in pure water $300(\mathrm{~N})$, with $1 \%$ aqueous extract of green leaves of $A$. monspessulanum (A), C. cogyggria (Cg), $Q$. 301 pubescens $(\mathrm{Q})$, P. halepensis $(\mathrm{P})$ and 1\% aqueous extract of senescent leaves of C. cogyggria $(\mathrm{Cs})$.

\begin{tabular}{lcrrrr}
\hline PSM & $\begin{array}{l}\text { Ceiling temperature } \\
\mathbf{T}_{\mathbf{c 5 0}}\left[{ }^{\circ} \mathbf{C}\right]\end{array}$ & $\begin{array}{l}\text { Thermal time constant } \\
\boldsymbol{\theta}_{\mathbf{T c}}\left[{ }^{\circ} \mathbf{C} \mathbf{~ d ~ d}\right]\end{array}$ & $\begin{array}{l}\text { Dispersion parameter } \\
\boldsymbol{\sigma}_{\mathbf{T c}}\left[{ }^{\circ} \mathbf{C}\right]\end{array}$ & $\mathbf{R}^{2}$ & $\mathbf{N}$ \\
\hline control & $37.92(34.05-41.80)$ & $102.98(77.05-128.90)$ & $-10.75(-13.24--8.26)$ & 0.78 & 143 \\
$\mathrm{~A}$ & $24.59(23.31-25.86)$ & $45.53(32.02-59.03)$ & $-3.42(-4.37--2.46)$ & 0.56 & 56 \\
$\mathrm{Cs}$ & $23.34(21.49-25.20)$ & $53.66(28.94-78.38)$ & $-4.69(-6.99--2.38)$ & 0.51 & 30 \\
$\mathrm{Cg}$ & $28.33(26.21-30.45)$ & $70.62(49.83-91.42)$ & $-4.70(-6.13--3.28)$ & 0.80 & 30 \\
$\mathrm{P}$ & $56.10(40.22-71.97)$ & $249.36(131.77-366.94)$ & $-22.84(-33.59--12.08)$ & 0.93 & 46 \\
$\mathrm{Q}$ & $31.46(28.33-34.58)$ & $126.92(86.52-167.32)$ & $-6.12(-8.10--4.14)$ & 0.89 & 20 \\
\hline
\end{tabular}


303 In contrast to suboptimal temperatures, at supra-optimal temperatures, PSM significantly affected not

304 only germination speed but also final germination percentages (Fig. 2B and 2C). More precisely,

305 final germination percentages at $25{ }^{\circ} \mathrm{C}$ were lowered compared to the control for compounds of $A$.

306 monspessulanum, $C$. cogyggria senescent and green leaves as well as $Q$. pubescens but not for $P$.

307 halepensis. Germination models showed that these lower final percentages were related to lower

308 ceiling temperature $\left(T_{c}\right)$ for germination (Table 3 ). This lowering of $T_{c}$ for germination was

309 accompanied by faster germination as indicated by the lower thermal time constants. Limitation of

310 germination at high temperatures was much stronger with extracts of $A$. monspessulanum green

311 leaves and senescent ones of $C$. coggygria compared to green leaves of $Q$. pubescens and $C$.

312 coggygria aqueous extracts (Fig. 2A). Interestingly the application of PSM from P. halepensis

313 increased Tc, enabling Linum perenne to germinate faster (Fig. 2A).
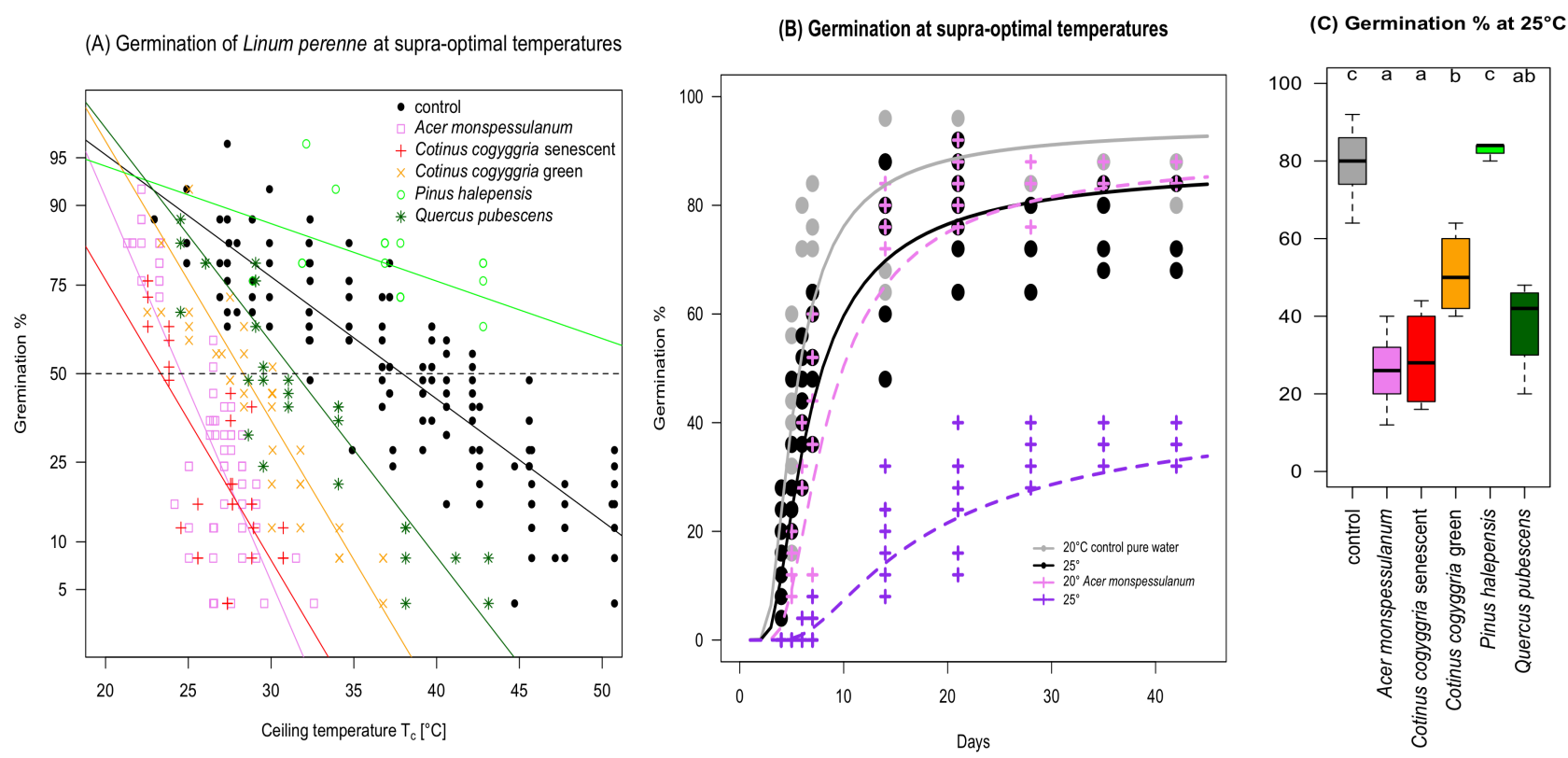

Fig. 2 (A) Effect of plant specialized metabolites (PSM) on high temperature limits for germination 316 of $L$. perenne seeds in pure water; germination time courses are standardized to ceiling temperatures, $317 \mathrm{~T}_{\mathrm{c}}$, using supra-optimal thermal time, note that the ceiling temperature for $50 \%$ germination, $\mathrm{T}_{\mathrm{c}(50)}$, corresponds to the intersection with the dashed line, slopes of regression lines equal $1 / \sigma_{\mathrm{Tc} 50}$, percentages are on probit-scale; intersections of temperatures with the $T_{c}$ indicate lower final germination percentages at that temperature; (B) Supra-optimal thermal time models and observed germination for L. perenne seeds under control and A. monspessulanum treatments; (C) Final germination percentages of $L$. perenne at $25^{\circ} \mathrm{C}$ under control and five PSM treatments, letters 
indicate significant differences $(\mathrm{p}<0.05, \mathrm{a}<\mathrm{b}<\mathrm{c})$ in a Tukey-test, PSM effect was significant according to a one-way ANOVA $(\mathrm{p}<0.001, \mathrm{~F}=37.88)$.

\section{Hydrotime model}

The hydrotime models using germination data obtained at different PEG solutions (Table 3 and Fig.

3) show that aqueous extracts from leaves of C. coggygria, A. monspessulanum and $Q$. pubescens increased base water potentials for germination (Table 4). This increase led to decreased final germination percentages when high PEG-concentrations were combined with extracts from $C$. coggygria, A. monspessulanum or $Q$. pubescens (Fig. 3B and C). This effect was accompanied by a decrease in the hydrotime constant $\theta_{\mathrm{H}}$ which is negatively correlated to base water potential $\Psi_{\mathrm{b}(50)}$ (Table 4). Extracts from needles of $P$. halepensis had the opposite effect, they decreased base water potential especially at $15{ }^{\circ} \mathrm{C}$ leading to faster and more complete germination.

Table 4 Hydrotime model parameters $\left(\Psi_{\mathrm{b}(50),} \sigma_{\psi 50}, \theta_{\mathrm{H}}\right)$ for germination at $15{ }^{\circ} \mathrm{C}$ for seeds of $L$. perenne; PSM: Germination in pure water (control), with $1 \%$ aqueous extract of green leaves of $A$. monspessulanum (A), C. cogyggria (Cg), Q. pubescens (Q), P. halepensis (P) and 1\% aqueous extract of senescent leaves of C. cogyggria (Cs).

\begin{tabular}{lllllr}
\hline PSM & $\begin{array}{l}\text { Base water potential } \\
\boldsymbol{\Psi}_{\mathbf{b}(\mathbf{5 0})}[\mathbf{M P a}]\end{array}$ & $\begin{array}{l}\text { Hydrotime } \boldsymbol{\theta}_{\mathbf{H}} \\
{[\mathbf{M P a} \mathbf{x} \mathbf{~}]}\end{array}$ & $\begin{array}{c}\boldsymbol{\sigma}_{\boldsymbol{w 5 0}} \\
{[\mathbf{M P a}]}\end{array}$ & $\mathbf{R 2}$ & $\mathbf{N}$ \\
\hline $\mathbf{1 5}^{\circ} \mathbf{C}$ & & & & & \\
\hline control & $-1.5(-1.81--1.19)$ & $11.22(8.68-13.76)$ & $0.63(0.48-0.77)$ & 0.83 & 130 \\
$\mathrm{~A}$ & $-0.67(-0.75--0.59)$ & $6.68(5.72-7.65)$ & $0.27(0.23-0.31)$ & 0.84 & 81 \\
$\mathrm{Cs}$ & $-0.33(-0.41--0.26)$ & $3.52(2.45-4.6)$ & $0.22(0.19-0.25)$ & 0.86 & 34 \\
$\mathrm{Cg}$ & $-0.99(-1.19--0.79)$ & $9.72(7.4-12.04)$ & $0.43(0.32-0.55)$ & 0.88 & 35 \\
$\mathrm{P}$ & $-1.83(-2.4--1.27)$ & $14.14(9.27-19.02)$ & $0.65(0.41-0.88)$ & 0.89 & 44 \\
$\mathrm{Q}$ & $-0.87(-1.05--0.7)$ & $8.3(6.26-10.34)$ & $0.31(0.23-0.39)$ & 0.82 & 30 \\
\hline $\mathbf{2 0} \mathbf{C}$ & & & & & \\
\hline control & $-0.73(-0.81--0.64)$ & $4.24(3.62-4.86)$ & $0.36(0.31-0.41)$ & 0.81 & 116 \\
$\mathrm{~A}$ & $-0.37(-0.45--0.29)$ & $3.26(2.47-4.04)$ & $0.26(0.2-0.32)$ & 0.72 & 62 \\
$\mathrm{Cs}$ & $-0.19(-0.24--0.14)$ & $2.36(1.86-2.87)$ & $0.2(0.16-0.23)$ & 0.86 & 25 \\
$\mathrm{Cg}$ & $-0.64(-0.76--0.52)$ & $5.11(3.94-6.28)$ & $0.28(0.21-0.35)$ & 0.76 & 38
\end{tabular}




\begin{tabular}{lllllr}
$\mathrm{P}$ & $-0.74(-0.85--0.63)$ & $4.85(3.98-5.72)$ & $0.39(0.32-0.47)$ & 0.87 & 54 \\
$\mathrm{Q}$ & $-0.62(-0.72--0.51)$ & $6.53(5.13-7.93)$ & $0.27(0.21-0.33)$ & 0.82 & 28 \\
\hline $\mathbf{2 5}^{\circ} \mathbf{C}$ & & & & & \\
\hline control & $-0.42(-0.48--0.36)$ & $3.01(2.55-3.47)$ & $0.34(0.3-0.38)$ & 0.81 & 97 \\
$\mathrm{~A}$ & $0.13(-0.29-0.02)$ & $3.72(1.78-5.66)$ & $0.47(0.29-0.64)$ & 0.61 & 27 \\
$\mathrm{Cs}$ & $-0.1(-0.36-0.16)$ & $4.06(-0.42-8.54)$ & $0.21(0.04-0.38)$ & 0.36 & 8 \\
$\mathrm{Cg}$ & $-0.13(-0.22--0.04)$ & $3.59(2.25-4.92)$ & $0.3(0.2-0.4)$ & 0.72 & 19 \\
$\mathrm{P}$ & $-0.33(-0.39--0.28)$ & $2.7(2.22-3.17)$ & $0.26(0.21-0.3)$ & 0.83 & 40 \\
$\mathrm{Q}$ & $-0.03(-0.21-0.15)$ & $3.15(0.73-5.58)$ & $0.29(0.15-0.43)$ & 0.54 & 15 \\
\hline
\end{tabular}

(A) Germination of Linum perenne at $15^{\circ} \mathrm{C}$

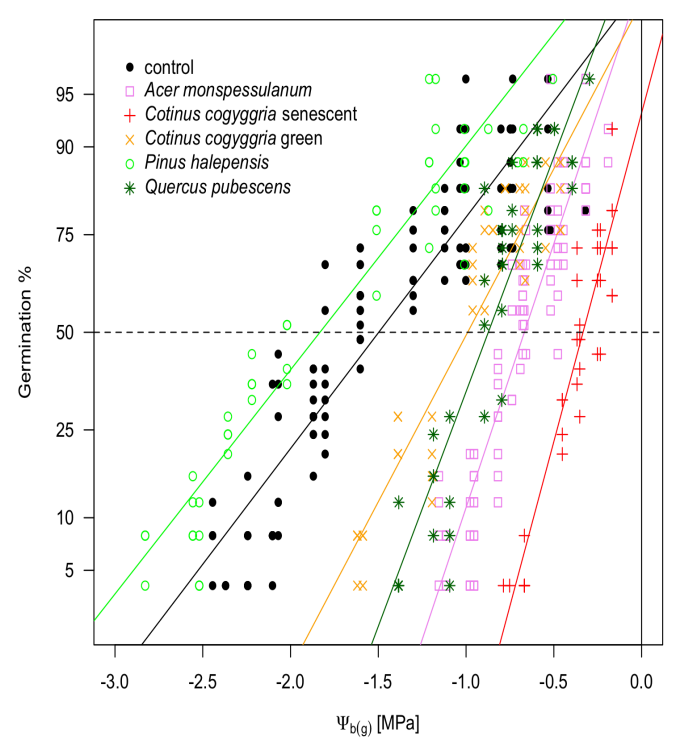

(B) Germination of Linum perenne at $25^{\circ} \mathrm{C}$

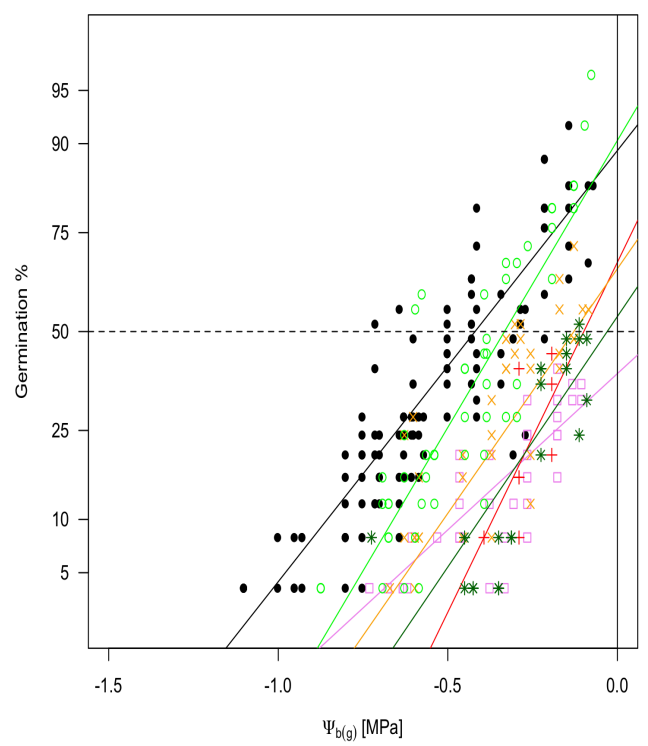

(C) Germination $\%$ at $25^{\circ} \mathrm{C} \&-0.2 \mathrm{MP}$

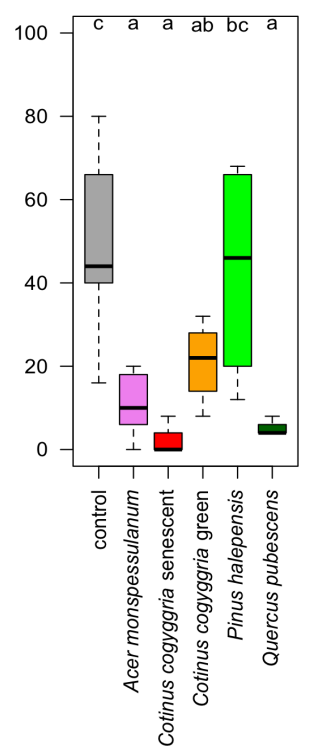

345

346

347

348

349

350

351

352

353

354

355

356

357

Fig. 3 Effect of plant specialized metabolites (PSM) on water requirements for germination of $L$. perenne seeds; (A) at $15^{\circ} \mathrm{C}(\mathrm{B})$ at $25^{\circ} \mathrm{C}$; germination time courses are standardized to base water potentials, $\Psi_{\mathrm{b}(\mathrm{g})}$, using hydrotime, note that the base water potential for $50 \%$ germination, $\Psi_{\mathrm{b}(50)}$, corresponds to the intersection with the dashed line, slopes of regression lines equal $1 / \sigma_{w 50}$, percentages are on probit-scale; intersections with the $\Psi_{\mathrm{b}(\mathrm{g})}=0$ line in (B) indicate lower final germination percentages in pure water; (C) Final germination percentages of L. perenne at $25^{\circ} \mathrm{C}$ and water-potential of $-0.2 \mathrm{Mpa}$ for control and five plant specialized metabolites (PSM) treatments, letters indicate significant differences $(\mathrm{p}<0.05)$ in a Tukey-test, PSM effect was significant in a oneway ANOVA $(\mathrm{p}<0.001, \mathrm{~F}=10.01)$.

The impact of PSM on water requirements for germination depended on the temperature (Fig. 3A and $3 \mathrm{~B})$. At $15^{\circ} \mathrm{C}$ PSM differed clearly among species in their effect on water requirements for germination, increasing water potentials necessary for germination, except for pine needles (Fig. 
$3583 \mathrm{~A}$ ). Contrastingly, at $25^{\circ} \mathrm{C}$, only aqueous extracts of green leaves of C. coggygria, $A$. 359 monspessulanum and Q. pubescens had a clear effect (Table 4). Particularly interesting was the effect 360 of $Q$. pubescens leaves, which tended to a stronger effect on water requirements at high compared to 361 low temperatures (Fig. 3). Final germination percentages decreased heavily when high temperatures 362 were combined with the effects of PSM (Fig. 3C).

363 Moreover, temperature also affected base water potentials for germination (Fig. 4A) by increasing 364 base water potentials for germination at $22^{\circ}$ and $25^{\circ} \mathrm{C}$ compared to $15^{\circ} \mathrm{C}$. However, we did not 365 combine hydrotime with thermal time models since our data from water potential gradients at $10^{\circ} \mathrm{C}$ 366 suggest a non-linear relationship between $\Psi_{\mathrm{b}(50)}$ and temperature (Fig. 4).

367

(A) Water requirements for Linum perenne germination

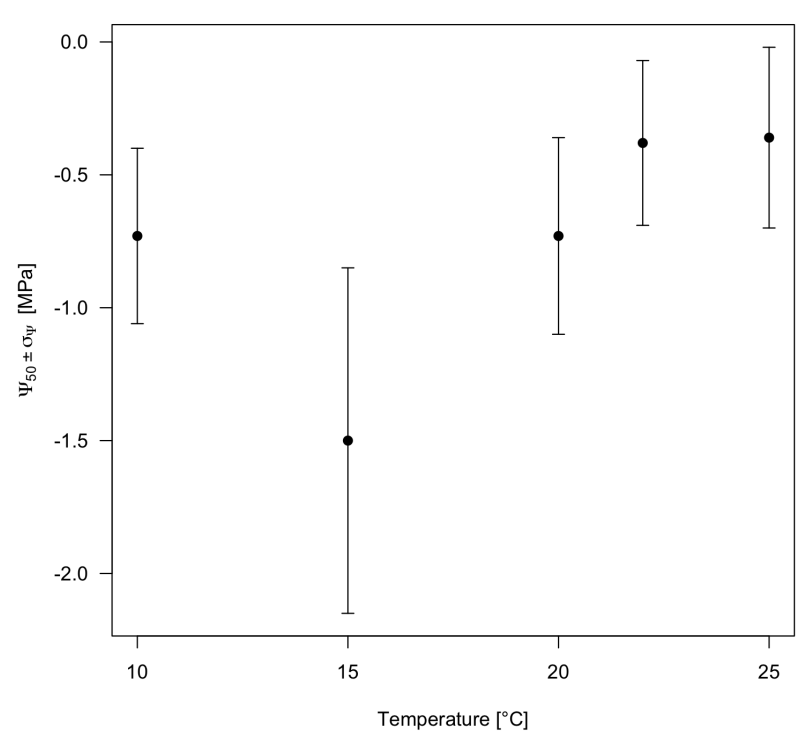

(B) Germination at different water potentials

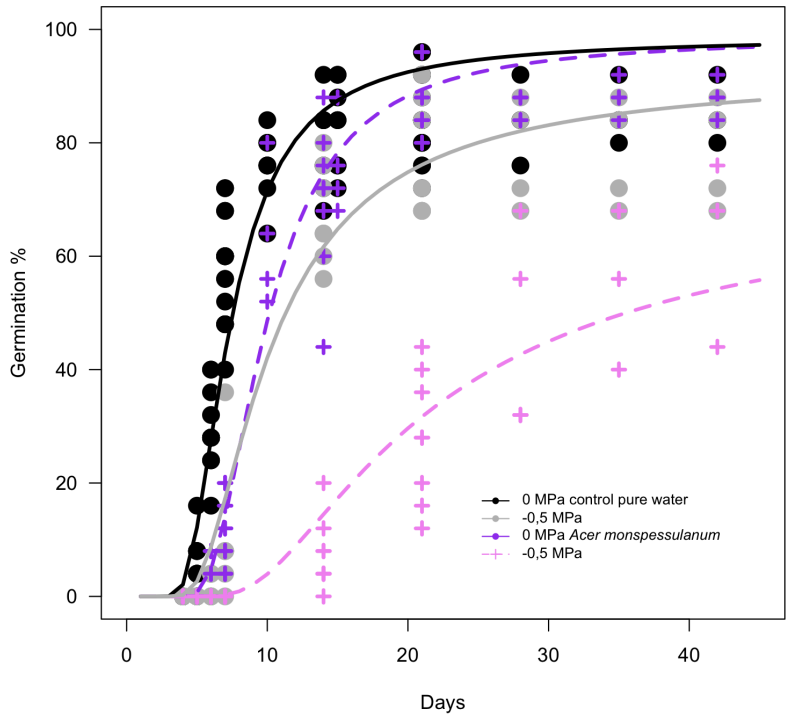

369 Fig. 4 (A) Change of base water potential with temperature for L. perenne seed germination without 370 plant specialized metabolites; (B) Germination and hydrotime model for L. perenne seed germination 371 in control and A. monspessulanum treatment for different water potentials fixed by polyethylene 372 glycol. 
(A) Germination on soil and in Petri-dishes at $25^{\circ} \mathrm{C}$

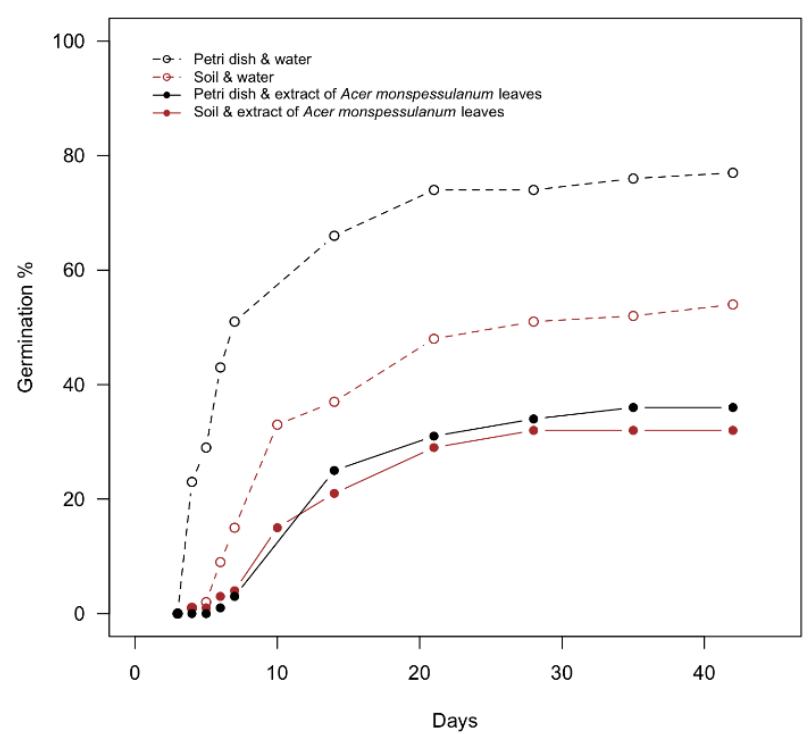

(B) Germination with temporary leaf-extract exposure at $25^{\circ} \mathrm{C}$

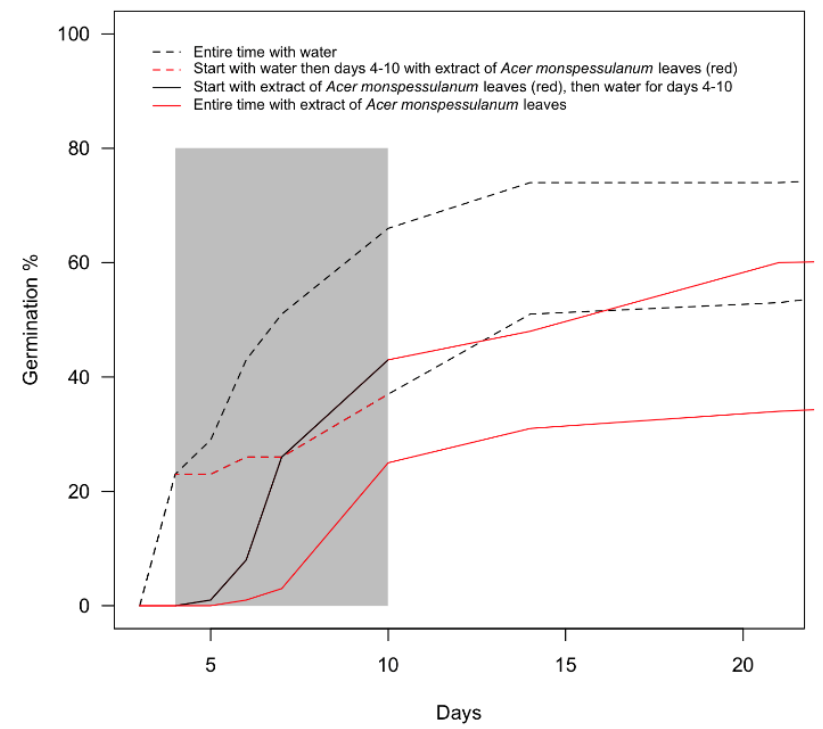

375

376

377

378

379

380

381

382

383

384

385

386

387

388

Fig. 5 (A) Interaction of soil and plant aqueous extracts on germination of $L$. perenne seeds (mean of four replicates); (B) Temporary exposure to aqueous $A$. monspessulanum leaf-extracts and germination for $L$. perenne seeds, the grey zone corresponds to temporary condition inversion at days 4 to 10 (mean of four replicates).

Our germination tests using natural soil showed that L. perenne seeds germinated faster and to higher percentages on filter paper compared to natural soil. Aqueous extracts of $A$. monspessulanum leaves had similar effects on germination on soil and filter paper, with slower germination and lower final percentages (Fig. 5A).

We also studied how a temporary exposition to A. monspessulanum leaf-extracts acted on germination of L. perenne seeds, which indicated that beginning germination is halted (Fig. 5B) and even after re-transfer to pure water did not recover initial percentages of germination. The inversed conditions indicate that germination during phases of pure water after exposure to leaf-extracts is fast and recovers partly compared to continuous exposure to leaf extracts (Fig. 5B). Interestingly, germination speed is only altered in the inversed conditions compared to the continuous conditions, and final percentages were intermediate and comparable for both temporary exposure treatments.

\section{Interaction GA3 and PSM at high temperature}


393 The two-way ANOVA of germination percentages, GA3 and leave extracts of $A$. monspessulanum 394 showed a significant interaction: when GA3 was added together with leave extracts, germination 395 percentages were twice as high as with leave extracts alone and they approached the GA3 and 396 control treatments (Fig. 6).

397

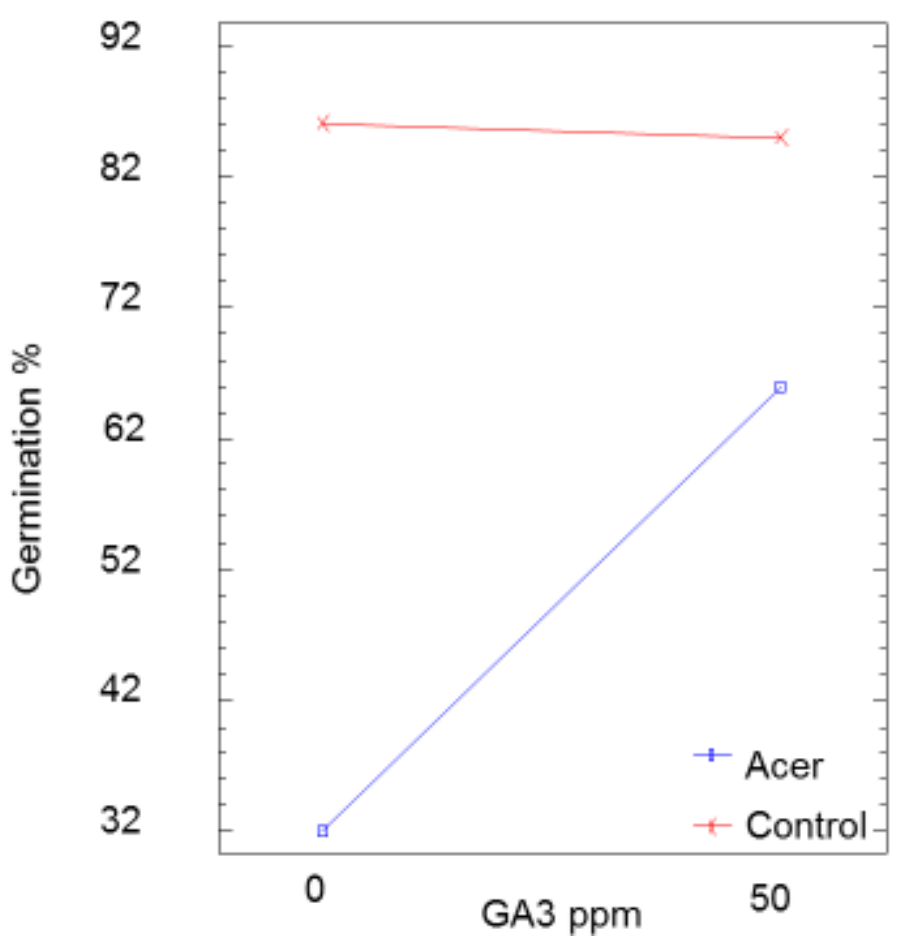

Fig. 6: Significant interaction of AG3 (50ppm) with aqueous A. monspessulanum leaf-extracts on germination of $L$. perenne seeds at $25^{\circ} \mathrm{C}(\mathrm{df}=1.12, \mathrm{~F}=8.3, \mathrm{p}=0.0138)$.

\section{Discussion}

402 We showed that plant specialized metabolites (PSM) from leaf extracts of Q. pubescens, A. 403 monspessulanum, C. cogyggria and P. halepensis modified germination with increasing effects at 404 high temperature and low water potentials. When PSM extracts were added, L. perenne seeds thus 
405 germinated under narrower conditions of water potential and upper range temperatures compared to 406 control experiments. Differences exist between PSM; for example aqueous extracts from $P$. 407 halepensis needles only affect little thermal and hydric conditions for germination compared to the 408 more limiting effect of C. coggygria, A. monspessulanum and $Q$. pubescens. The thermal time model 409 for temperatures below the optimum showed an increase in thermal time needed for germination 410 when PSM are added. Whereas the effect of PSM on germination timing has never been quantified, 411 these data join previous observations from Einhellig and Eckrich (1984) who found that the amount 412 of ferulic acid needed to inhibit germination in grain sorghum and soybeans was lower under higher 413 temperatures. Similarly, Ruprecht et al. (2008) found that the allelopathic effect of grasses on 414 germination of forbs was stronger at higher temperature. Together with our data, this suggest that 415 allelopathic effects tend to be stronger at higher temperatures for some ecosystems, a finding for 416 which we now provide a quantified model showing the gradual increase of PSM with increasing 417 temperatures.

418 Besides, our data highlight that PSM affect the use of water during germination of $L$. perenne seeds. 419 Aqueous extracts from C. coggygria, A. monspessulanum and Q. pubescens leaves increased the base 420 water potentials for germination of $L$. perenne. To date, no study has provided a quantitative model 421 on how PSM interact with lowered water potentials on germination. The only other work by 422 Einhellig (1989) showed that a lowered water availability interacted with PSM by increasing impacts 423 on germination. Our models now quantify, for several source-species, how water potentials and PSM 424 interact and highlight that germination percentages decrease still linearly with water potentials when 425 PSM are added (Fig. 3A).

426 Our analysis also suggests that high temperatures and low water potentials interact with PSM in their 427 effect on germination: L. perenne seeds germinate over much narrower conditions in terms of water 428 potentials and upper range temperatures in presence of PSM. Our data show how high temperatures 
429 increase the water potential needed to trigger germination. In this setting, PSM have stronger effects 430 or even inhibit completely germination in combined temperature and drought stresses. No previous 431 work has considered the combined effects of PSM, temperature and drought on germination. 432 However the addition of both processes discussed above and their consistency with previous works 433 (Einhellig and Eckrich 1984; Ruprecht et al. 2008) suggest that increased effects of PSM at 434 simultaneously high temperatures and low water potentials are probably a general phenomenon. 435 Negative effects of PSM of a range of source species on seed germination have been documented for 436 various target plants (Bogatek et al. 2006; Herranz et al. 2006; Jefferson and Pennacchio 2003; 437 Ridenour and Callaway 2001; Ruprecht et al. 2008; Souto et al. 2001). Our data precise this picture 438 by showing that effects are smaller at low temperature and concern germination speed while at high 439 temperature and low moisture, PSM effects are strongest and impede a fraction of seeds to 440 germinate. Since there are many studies that document negative effects of PSM on germination, it 441 seems reasonable to assume that effects of PSM of four Mediterranean woody plants on seed 442 germination of L. perenne might also be observed in other systems of source and target species.

443 In our system, natural soil did not decrease the effect of aqueous leaf extracts, although several 444 works indicated that PSM might be adsorbed to soil particles or transformed to less active 445 compounds (Kobayashi 2004; Shaw et al. 2006). Aqueous extracts of A. monspessulanum leaves 446 have very similar effects on germination under soil and filter paper. However, L. perenne seeds 447 germinate faster and to higher percentages on filter paper compared to natural soil. This finding 448 corroborates the previous work by Herranz and coworkers (2006) who showed that soil from below 449 Cistus shrubs does not impede the effect of PSM and shows even stronger effect on germination 450 compared to simple aqueous extracts. These findings underline that the gradual increasing effect of 451 temperature and drought stresses together with PSM play a role in the field, and that PSM might 452 decrease germination in concert with climatic conditions for herbaceous plants in many ecosystems. 
453 Finally, temporary exposure to leaf extracts can also impact germination, since leaf-extracts 454 decreased germination speed and final percentages and even after re-transfer into environments 455 without PSM, germination recovers only partly, a finding that is very interesting in the context of 456 how PSM act in the field. A part of the seed population is permanently inhibited to germinate even 457 after short exposure and subsequent absence of PSM. This ensures that PSM decrease germination of 458 plants in the field, even if high rainfall events might dilute PSM. Moreover, it also suggests that PSM 459 intervene in the physiological control of germination by changing the germination inducing 460 pathways. It would be interesting to study further on if the non-germinated seeds die or if dormancy461 release mechanisms such as chilling or drought might release these seeds from the inhibitory effects 462 of PSM.

463 One may argue that PSM might only interact with water usage by plants and not directly with how 464 temperature affects plants, since temperature decreases base water potentials for germination in most 465 species. This decrease in base water potential would then be sufficient to explain the effects of PSM 466 on the high and dry limits of germination. A single signaling pathway targeted on sensing of water 467 potential could achieve this. Previous work shows that PSM can increase anti-gibberellin effects and 468 ABA-synthesis (Courtois and Olofsdotter 1998; Kruse et al. 2000) that are known to limit water 469 uptake during germination (Schopfer and Plachy 1984). This is also in congruence with our finding 470 that GA3 reduces the effects of PSM suggesting PSM to block GA3 synthesis in an early stage of 471 germination and to prevent germination as sustained by other works (Terzi and Kocaçalişkan 2010; 472 Zhang et al. 2012). This mechanism may be based on reduced water uptake impairing the GA3 473 synthesis. Previous studies showed that allelochemicals (e.g. 3,4-dihydroxy-acetophenone, DHAP) 474 can have an impact on hormonal balance in plants (Kaya et al. 2015; Turker et al. 2008) increasing 475 ABA and decreasing GA3 levels (Kaya et al. 2015; Yang et al. 2017). However, Ruan et al. (2016) 476 also showed that DHAP has more important effects at high temperature, maybe because at high 
477 temperature, allelochemicals can be transformed into more active compounds that interfere with 478 hormonal balance (Pedrol et al. 2006). In our data, we also observe stronger effects of PSM at higher 479 temperatures (Fig. 2), resulting in steeper slopes for the relation between germination percentages 480 that germinate at the high temperature limits, when PSM are present. An exception were aqueous 481 extracts from P. halepensis which increased germination germination speed (Table 3) but did not had 482 a significant effect on final percentages (Fig. 2).

483 We cannot exclude that the source species used here have been in contact with L. perenne in its 484 recent evolutionary history and that PSM were implicated in biological interactions encompassing 485 signalization and defense between these plants and Linum. This might have induced some adaptation 486 of Linum to these source plants as has been elucidated by Ehlers \& Thompson (2004) for Bromus 487 erectus and Thymus vulgaris chemotypes in more open Mediterranean habitats. It is also possible 488 that our -commercial- seed source is more sensible to PSM than wild populations that evolved in 489 direct contact with the woody plants studied here, and we think that this is a very interesting question 490 for future studies. Since low germination speed enhances the building of a permanent soil seed bank 491 (Saatkamp et al. 2011), our data might alternatively suggest that detection of PSM at the germination 492 stage is a way for subordinate species to avoid negative effects of dominant woody plants on the later 493 seedling and adult plant stages. These results highlight that chemical interactions of dominant and 494 subordinate species below ground need to receive greater attention in view of improving our 495 understanding of seed trait function (Saatkamp et al. 2019). Together with earlier work (Fernandez et 496 al. 2013) data presented here suggest that Mediterranean woody species can permanently limit 497 germination of subordinate plants in their habitat by decreasing germination in limiting conditions 498 such as during drought and high temperatures. 
This study was supported by the grant ANR-12-BSV7-0016-01 of the French Agence Nationale pour la Recherche through the project SecPriMe to CF, the Région Provence Alpes Côte d'Azur supported this work through its Gévoclé grant to AS. The OHP site belongs to SOERE F-ORE-T, and SOERE TEMPO supported by Ecofor, Allenvi and the French national research infrastructure, ANAEE-F, www.anaee-france.fr.

\section{Author Contributions statement}

- $\mathrm{HH}, \mathrm{AS}, \mathrm{TG}, \mathrm{CF}$ and $\mathrm{ABM}$ conceived and designed the research;

- $\mathrm{HH}$ and AS collected the data;

- $\mathrm{HH}$ and AS analyzed and interpreted the data;

- $\mathrm{HH}, \mathrm{AS}$, led the writing and HH, AS, TG, CF, JR, ABM revised the manuscript.

\section{References}

Allemann I, Cawood ME, Allemann J (2016) Influence of abiotic stress on Amaranthus cruentus allelopathic properties. S Afr J Bot: 306.

Anderson RC, Loucks OL (1966) Osmotic pressure influence in germination tests for antibiosis. Science 152: 771-773.

Arène F, Affre L, Doxa A, Saatkamp A (2017) Temperature but not moisture response of germination shows phylogenetic constraints while both interact with seed mass and life span. Seed Science Research 27: 110-120.

Benech-Arnold RL, Gualano N, Leymarie J, Côme D, Corbineau F (2006) Hypoxia interferes with ABA metabolism and increases ABA sensitivity in embryos of dormant barley grains. J Exp Bot 57: 1423-1430.

Blanco JA (2007) The representation of allelopathy in ecosystem-level forest models. Ecol Model 209: 65-77.

Bogatek R, Gniazdowska A, Zakrzewska W, Oracz K, Gawronski SW (2006) Allelopathic effects of sunflower extracts on mustard seed germination and seedling growth. Biol Plant 50: 156-158.

Bolker B (2017) Maximum likelihood estimation and analysis with the bbmle package.

Bradford KJ (2002) Applications of hydrothermal time to quantifying and modeling seed germination and dormancy. Weed Sci 50 248-260.

Bradford KJ, Benech-Arnold RL, Côme D, Corbineau F (2008) Quantifying the sensitivity of barley seed germination to oxygen, abscisic acid, and gibberellin using a population-based threshold model. J Exp Bot 59: 335-347.

Briggs JS, Wall SBV, Jenkins SH (2009) Forest rodents provide directed dispersal of Jeffrey pine seeds. Ecology 90: 675-687. doi: 10.1890/07-0542.1.

Chomel M, Guittonny-Larchevêque M, Fernandez C, Gallet C, DesRochers A, Paré D, Jackson BG, Baldy V (2016) Plant secondary metabolites: a key driver of litter decomposition and soil nutrient cycling. J Ecol 104: 1527-1541.

Courtois B, Olofsdotter M (1998) Incorporating the allelopathy trait in upland rice breeding programs. Allelopathy in Rice: 57-68.

Ehlers BK, Thompson J (2004) Do co-occurring plant species adapt to one another? The response of Bromus erectus to the presence of different Thymus vulgaris chemotypes. Oecologia 141: 511-518. 
Einhellig FA (1989) Interactive effects of allelochemicals and environmental stress. Phytochemical Ecology: allelochemicals, mycotoxins and insect pheromones and allomones.

Einhellig FA (1996) Interactions involving allelopathy in cropping systems. Agron J 88: 886-893.

Einhellig FA, Eckrich PC (1984) Interactions of temperature and ferulic acid stress on grain sorghum and soybeans. J Chem Ecol 10: 161-170.

Fernandez C, Lelong B, Vila B, Mévy J-P, Robles C, Greff S, Dupouyet S, Bousquet-Mélou A (2006) Potential allelopathic effect of Pinus halepensis in the secondary succession: an experimental approach. Chemoecology 16: 97-105. doi: 10.1007/s00049-006-0334-z.

Fernandez C, Monnier Y, Santonja M, Gallet C, Weston LA, Prévosto B, Saunier A, Baldy V, Bousquet-Mélou A (2015) The impact of competition and allelopathy on the trade-off between plant defense and growth in two contrasting tree species. Frontiers in plant science 7: 594-594.

Fernandez C, Santonja M, Gros R, Monnier Y, Chomel M, Baldy V, Bousquet-Mélou A (2013) Allelochemicals of Pinus halepensis as drivers of biodiversity in Mediterranean open mosaic habitats during the colonization stage of secondary succession. J Chem Ecol 39: 298-311.

Flematti GR, Ghisalberti EL, Dixon KW, Trengove RD (2004) A compound from smoke that promotes seed germination. Science 305: 977-977.

Gatti AB, Takao LK, Pereira VC, Ferreira AG, Lima MIS, Gualtieri SCJ (2014) Seasonality effect on the allelopathy of cerrado species. Braz J Biol 74: S064-S069.

Gavinet J, Prévosto B, Bousquet-Mélou A, Gros R, Quer E, Baldy V, Fernandez C (2018) Do littermediated plant-soil feedbacks influence Mediterranean oak regeneration? A two-year pot experiment. Plant Soil 430: 59-71.

Gavinet J, Santonja M, Baldy V, Hashoum H, Peano S, Tchong T, Gros R, Greff S, Fernandez C, Bousquet-Mélou A (2019) Phenolics of the understory shrub Cotinus coggygria influence Mediterranean oak forests diversity and dynamics. For Ecol Manage 441: 262-270.

Giorgi F, Lionello P (2008) Climate change projections for the Mediterranean region. Global Planet Change 63: 90-104.

Hashoum H, Santonja M, Gauquelin T, Saatkamp A, Gavinet J, Greff S, Lecareux C, Fernandez C, Bousquet-Mélou A (2017) Biotic interactions in a Mediterranean oak forest: role of allelopathy along phenological development of woody species. European Journal of Forest Research 136: 699-710.

Herranz JM, Ferrandis P, Copete MA, Duro EM, ZalacaÃ-n A (2006) Effect of allelopathic compounds produced by Cistus ladanifer on germination of 20 Mediterranean taxa. Plant Ecol 184: 259-272.

Hoerling M, Eischeid J, Perlwitz J, Quan X, Zhang T, Pegion P (2012) On the increased frequency of Mediterranean drought. J Clim 25: 2146-2161.

Holdsworth MJ, Finch-Savage WE, Grappin P, Job D (2008) Post-genomics dissection of seed dormancy and germination. Trends Plant Sci 13: 7-13.

Huang Z, Liu S, Bradford KJ, Huxman TE, Venable DL (2016) The contribution of germination functional traits to population dynamics of a desert plant community. Ecology 97: 250-261.

IUSS Working Group WRB (2006) World reference base for soil resources. World Soil Resources Report 103.

Jefferson L, Pennacchio M (2003) Allelopathic effects of foliage extracts from four Chenopodiaceae species on seed germination. J Arid Environ 55: 275-285.

Kaya Y, Aksakal O, Sunar S, Erturk FA, Bozari S, Agar G, Erez ME, Battal P (2015) Phytotoxical effect of Lepidium draba L. extracts on the germination and growth of monocot (Zea mays L.) and dicot (Amaranthus retroflexus L.) seeds. Toxicol Ind Health 31: 247-254. 
Klanderud K (2005) Climate change effects on species interactions in an alpine plant community. J Ecol 93: 127-137.

Kobayashi K (2004) Factors affecting phytotoxic activity of allelochemicals in soil. Weed Biol Manage 4: 1-7.

Kruse M, Strandberg M, Strandberg B (2000) Ecological effects of allelopathic plants-a review. NERI Technical Report 315.

Liptay A, Schopfer P (1983) Effect of water stress, seed coat restraint, and abscisic acid upon different germination capabilities of two tomato lines at low temperature. Plant Physiol 73: 935-938.

Lobón NC, Gallego JCA, Diaz TS, Garcia JCE (2002) Allelopathic potential of Cistus ladanifer chemicals in response to variations of light and temperature. Chemoecology 12: 139-145.

Ma Z, Fang T, Thring RW, Li Y, Yu H, Zhou Q, Zhao M (2015) Toxic and non-toxic strains of Microcystis aeruginosa induce temperature dependent allelopathy toward growth and photosynthesis of Chlorella vulgaris. Harmful Algae 48: 21-29.

Melkania NP (1992) Allelopathy in forest and agroecosystems in the Himalayan region. Allelopathy. Springer.

Michel BE (1983) Evaluation of the water potentials of solutions of polyethylene glycol 8000 both in the absence and presence of other solutes. Plant Physiol 72: 66-70.

Ni BR, Bradford KJ (1992) Quantitative models characterizing seed germination responses to abscisic acid and osmoticum. Plant Physiol 98: 1057-1068.

Oueslati O, Ben-Hammouda M, Ghorbal MH, Guezzah M, Kremer RJ (2005) Barley autotoxicity as influenced by varietal and seasonal variation. Journal of Agronomy and Crop Science 191: 249-254.

Rasmann S, Agrawal AA (2011) Latitudinal patterns in plant defense: evolution of cardenolides, their toxicity and induction following herbivory. Ecol Lett 14: 476-483. doi: 10.1111/j.14610248.2011.01609.x.

Rice EL (1984) Allelopathy, New York.

Ridenour WM, Callaway RM (2001) The relative importance of allelopathy in interference: the effects of an invasive weed on a native bunchgrass. Oecologia 126: 444-450.

Ruan X, Pan CD, Liu R, Li ZH, LI SL, Jiang DA, Zhang JC, Wang G, Zhao YX, Wang Q (2016) Effects of climate warming on plant autotoxicity in forest evolution: a case simulation analysis for Picea schrenkiana regeneration. Ecol Evol 6: 5854-5866.

Ruprecht E, Donath TW, Otte A, Eckstein RL (2008) Chemical effects of a dominant grass on seed germination of four familial pairs of dry grassland species. Seed Science Research 18: 239248.

Saatkamp A, Affre L, Dutoit T, Poschlod P (2011) Germination traits explain soil seed persistence across species: the case of Mediterranean annual plants in cereal fields. Ann Bot 107: 415415.

Saatkamp A, Cochrane A, Commander L, Guja LK, Jimenez-Alfaro B, Larson J, Nicotra A, Poschlod P, Silveira FA, Cross AT, Dalziell EL, Dickie J, E ET, Fidelis A, Fuchs A, Golos PJ, Hope M, Lewandrowski W, Meritt DJ, Miller BP, Miller RG, Offord CA, Ooi MKJ, Satyantis A, Sommerville KD, Tangney R, Tomlinson S, Turner S, Walck JL (2019) A research agenda for seed-trait functional ecology. New Phytol 221: 1764-1775.

Schopfer P, Plachy C (1984) Control of seed germination by abscisic acid: II. Effect on embryo water uptake in Brassica napus L. Plant Physiol 76: 155-160.

Scognamiglio M, D’Abrosca B, Esposito A, Pacifico S, Monaco P, Fiorentino A (2013) Plant growth inhibitors: allelopathic role or phytotoxic effects? Focus on Mediterranean biomes. Phytochem Rev 12: 803-830. 
Shaw LJ, Morris P, Hooker JE (2006) Perception and modification of plant flavonoid signals by rhizosphere microorganisms. Environ Microbiol 8: 1867-1880. doi: 10.1111/j.14622920.2006.01141.x.

Souto XC, Bolaño JC, González L, Reigosa M (2001) Allelopathic effects of tree species on some soil microbial populations and herbaceous plants. Biol Plant 44: 269-275.

Souto XC, Gonzales L, Reigosa MJ (1994) Comparative analysis of allelopathic effects produced by four forestry species during decomposition process in their soils in Galicia (NW Spain). J Chem Ecol 20: 3005-3015.

Terzi I, Kocaçalişkan I (2010) The effects of gibberellic acid and kinetin on overcoming the effects of juglone stress on seed germination and seedling growth. Turkish Journal of Botany 34: 6772.

Turker M, Battal P, Agar G, Gulluce M, Sahin F, Erez M, Yildirim N (2008) Allelopathic effects of plants extracts on physiological and cytological processes during maize seed germination. Allelopathy Journal 21: 273.

Vesty EF, Saidi Y, Moody LA, Holloway D, Whitbread A, Needs S, Choudhary A, Burns B, McLeod D, Bradshaw SJ, Bae H, King BC, Bassel GW, Simonsen HT, Coates JC (2016) The decision to germinate is regulated by divergent molecular networks in spores and seeds. New Phytol 211: 952-966. doi: 10.1111/nph.14018.

Vyvyan JR (2002) Allelochemicals as leads for new herbicides and agrochemicals. Tetrahedron 58: 1631-1646.

Wang R-L, Zeng R-S, Peng S-L, Chen B-M, Liang X-T, Xin X-W (2011) Elevated temperature may accelerate invasive expansion of the liana plant Ipomoea cairica. Weed Res 51: 574-580.

Williams DH, Stone MJ, Hauck PR, Rahman SK (1989) Why are secondary metabolites (natural products) biosynthesized? J Nat Prod 52: 1189-1208.

Yang L, Ruan X, Jiang D, Zhang J, Pan C, Wang Q (2017) Physiological effects of autotoxicity due to DHAP stress on Picea schrenkiana regeneration. PloS one 12: e0177047.

Zhang J, Wang Y, Yang T, Jin H, Zhang J (2012) Use of gibberellic acid to overcome the allelopathic effect of a range of species on the germination of seeds of Gentiana rigescens, a medicinal herb. Seed Science and Technology 40: 443-447. 